\title{
Geneze fosfátu v jeseneckých vápencích konicko-mladečského pruhu (drahanský faciální vývoj moravskoslezského paleozoika na Moravě)
}

The genesis of phosphates in the Jesenec Limestone of the Konice-Mladeč Belt (Drahany Facies Domain of the Moravian-Silesian Paleozoic in Moravia)

\section{David Buriánek ${ }^{1} \rightarrow$, Radek Streit ${ }^{1,2}$}

${ }^{1}$ Česká geologická služba, Leitnerova 22, 60200 Brno, ČR

2Ústav geologických věd PřF MU, Kotlářská 2, 61137 Brno, ČR

Key words:

petrography, apatite, limestones, Famennian, Tournaisian, Rhenohercynian foreland basin, Bohemian Massif

$\Xi$ david.burianek@geology.cz

Editor:

Marek Slobodník
Doporučená citace článku: Buriánek, D., Streit, R. (2021). Geneze fosfátu v jeseneckých vápencích konicko-mladečského pruhu (drahanský faciální vývoj moravskoslezského paleozoika na Moravě). - Geologické výzkumy na Moravě a ve Slezsku, 28, 1-2, 13-19.

https://doi.org/10.5817/GVMS202114508

\begin{abstract}
Jesenec Limestone of the Famennian to Tournaisian age belongs to the Drahany Facies Domain (Development) of the Moravian-Silesian Paleozoic sedimentary sequence. Massive micritic and biosparitic limestone layers occasionally alternate with sandy limestone and limestone with an admixture of pyroclastic material.

Several $\mathrm{mm}$ to $25 \mathrm{~mm}$ angular and rounded fragments of black phosphorites were found in the investigated limestones crop out in the Konice-Mladeč Belt (sediments and volcanites) north of the villages of Dzbel and Jesenec. We use an optical microscope and electron probe microanalysis to classify and interpret these phosphorites. Based on shape, phosphorite particles we divided into two principal groups: angular intraclasts and rounded concretions. Fine-grained brecciated intraclasts are fragments of phosphorite layers formed on the surface of carbonate sediment (probably near the volcanoes) in a shallow-water environment. The destruction of these phosphate crusts may have been due to waves associated with storm activity or volcanic eruptions.

Fine-grained phosphorite concretions comprise predominantly dark-colored subhedral to anhedral fluorapatite (0.07-0.14 wt. \% FeO; up to $0.04 \mathrm{wt}$. \% $\mathrm{MnO}$ ) with interspersed calcite (0.06-0.14 hm. \% FeO; up to $0.43 \mathrm{wt}$. \% MgO) and quartz crystals. Apatite spherulites up to $0.2 \mathrm{~mm}$ in diameter are locally visible. Rare present pyrite crystals and their relics indicate polyphase evolution, including partial replacement of pyrite by apatite. We assume the crystallization of pyrite in an anoxic environment as the first phase of the process. The low $\mathrm{pH}$ of pore waters due to pyrite oxidation led to the dissolution of the biogenic phosphate and its subsequent precipitation in the form of concretions.
\end{abstract}

\section{Úvod}

Severně od obcí Dzbel a Jesenec vystupují vápence, břidlice, vulkanoklastické a vulkanické horniny jižní části konicko-mladečského pruhu. Jedná se o devonské až spodně karbonské sedimenty drahanského faciálního vývoje moravskoslezského paleozoika na Moravě (Svoboda a Prantl 1951, 1954; Chlupáč 1959; Barth 1960; Kettner 1965; Bábek et al. 1994; Bábek a Janoška 1997; Bábek 1996; 1997; 2001a; b; Bábek et al. 2006). Některé z těchto vápenců obsahují fragmenty fosforitů (Bábek et al. 1994). Tento fenomén nebyl prozatím ve zmíněných vápencích detailně studován. Cílem této práce je texturně a mineralogicky charakterizovat nalezené vzorky fosforitů. Zmíněné údaje mohou pomoci při interpretaci vzniku těchto zajímavých hornin. 


\section{Geologie a stratigrafická pozice vápenců}

Konicko-mladečský pruh je $\mathrm{z}$ regionálně geologického hlediska součástí moravskoslezské oblasti a bývá řazen do rhenohercynské zóny (Engel a Franke 1983; Finger a Steyrer 1995). Jedná se o vulkanosedimentární komplex devonského stáří, jehož stavba je důležitá pro pochopení paleozoického vývoje této části Českého masivu. Paleozoické horninové sekvence vystupují na povrch v prostoru Drahanské vrchoviny, Hrubého i Nízkého Jeseníku a Tišnovska. Zmíněné horninové sekvence můžeme členit na pět základních vývojů (Zukalová a Chlupáč 1982): vrbenský, drahanský (pánevní), Moravského krasu (platformní), ludmírovský (přechodný) a tišnovský (okrajový).

Devonská sedimentace probíhala v podmínkách zaobloukové pánve na jv. okraji Laurussie, která vznikla extenzí krystalinického podkladu budovaného horninami brunovistulika (Kalvoda et al. 2008). Během karbonu přešla v této oblasti sedimentace do flyšové a byla ukončena uhlonosnou molasou (Kumpera 1983; Dvořák 1994; Chlupáč et al. 2002; Kalvoda a Bábek 2010). Devonská až spodnokarbonská sedimentace tedy reprezentuje vývojový cyklus na pasivním okraji, který začíná extenzí a končí kompresním uzavřením sedimentační pánve a variskou orogenezí (např. Hladil 1994).

V jižní části konicko-mladečského pruhu (obr. 1a) začíná litostratigrafický sled drahanského faciálního vývoje klastickými sedimenty (obr. 1b). Jedná se o svrchně emské až spodně eifelské polymiktní až oligomiktní slepence (obr. 1b), křemenné pískovce, drobové pískovce až droby (Chlupáč a Svoboda 1963). V jejich nadloží místy vystupují vápnité břidlice stínavsko-chabičovského souvrství (obr. 1b) s polohami biodetritických vápenců. Bazální klastika a stínavsko-chabičovské souvrství byly ukládány na krystalinické horniny brunovistulika.

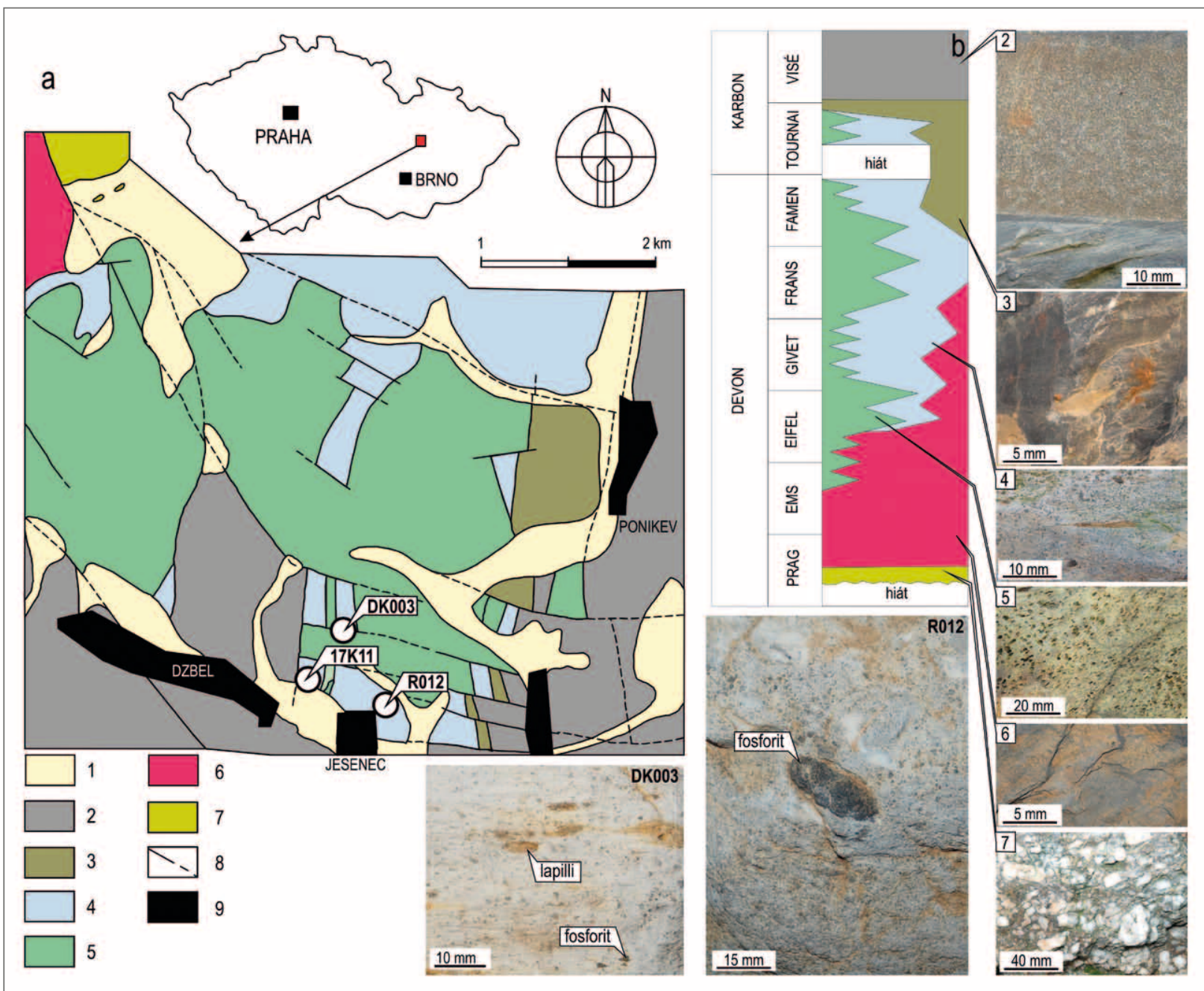

Obr. 1: Zjednodušená geologická mapa (a) a stratigrafický sloupec (b) pro jižní část konicko-mladečského pruhu (upraveno podle Bartha 1964 a Bábka et al. 2006): 1 - kenozoické fluviální sedimenty, aluvia a hlíny; 2 - karbonský flyš (droby a břidlice); 3 - ponikevské souvrství (břidlice s lydity); 4 - jesenecké vápence; 5 - vulkanický komplex; 6 - stínavsko-chabičovské souvrství (vápnité břidlice); 7 - bazální klastika (polymiktní až oligomiktní slepence, křemenné pískovce až droby); 8 - zlomy; 9 - obce (DK003 a R012: typické makrovzorky vápenců s fosfority).

Fig. 1: Simplified geological map (a) and stratigraphic column (b) for the southern part of the Konice-Mladeč Belt (adapted from Barth 1964 and Bábek et al. 2006): 1 - Cenozoic fluvial sediments, alluvium, and soil; 2 - Carbonian flysch (greywacke and shale); 3 - Ponikev Formation (shales with lydites); 4 - Jesenec Limestone; 5 - volcanic complexes; 6 - Stínava-Chabičov Formation (calcareous shales); 7 - basal clastics (polymictic to oligomictic conglomerates, quartz sandstones to greywacke); 8 - faults; 9 - villages (DK003 a R012: typical hand specimens of limestones with phosphorites). 
V nadloží tohoto komplexu vystupují jesenecké vápence. Dominantně se jedná o sled mikritických, biomikritických až biodetritických vápenců (obr. 1b), který především při bázi obsahuje také polohy písčitých vápenců a vápencových brekcií s korálovou faunou a fosfority (Chlupáč a Svoboda 1963; Bábek 2001a; b). Stratigrafický rozsah jeseneckých vápenců byl biostratigraficky zařazen do stř̌edního eifelu až svrchního tournai (Bábek et al. 1994; Bábek 2001a; b). Jesenecké vápence nejsou z litostratigrafického hlediska jednoznačně definovány. Místy jsou jasně odlišitelné od podloží a nadloží a mohou být chápány jako souvrství, avšak vápence se také prostorově zastupují s produkty podmořského vulkanismu a lokálně mají charakter drobných vložek, což může jejich definici snižovat na úroveň členu (Zukalová a Chlupáč 1982). Z tohoto důvodu používáme pro tyto horniny termín jesenecké vápence. Produkty vulkanické aktivity jsou dominantně reprezentovány bazickými lávami (obr. 1b) a vulkanoklastiky (hyaloklastity). Méně časté jsou polštářové lávy, vložky páskovaných magnetitových a hematitových rud a vápenců (Barth 1964). Kontakty mezi vulkanickými a vulkanoklastickými horninami a jeseneckými vápenci jsou tektonicky modifikované, avšak obecně se předpokládá, že se ty to dvě facie laterálně zastupují (Chlupáč 1964; Zukalová a Chlupáč 1982; Bábek et al. 1994). Vulkanity patrně tvořily podmořské elevace a v jejich blízkosti docházelo k usazování biogenních jeseneckých vápenců (Chlupáč 1964; Streit 2019). Na jesenecké vápence nasedá ponikevské souvrství (famen/tournai, obr. 1b) reprezentované břidlicemi s polohami radiolaritů (Chlupáč a Svoboda 1963; Dvořák 1994, 1996). Př́tomnost radiolaritů indikuje větší hloubku sedimentace, která se občas nacházela pod úrovní karbonátové kompenzační hloubky (Carbonate Compensation Depth). Poté následovala flyšová sedimentace (obr. 1b) drahanského faciálního vývoje reprezentovaná protivanovským souvrstvím (visé; Chlupáč et al. 2002; Kalvoda a Bábek 2010).

Vývoj vápencové sedimentace byl poměrně komplikovaný s řadou hiátů a přerušení sedimentace, a to zejména na rozhraní devonu a karbonu (Svoboda a Prantl 1951; Bábek et al. 1994; Bábek 2001a, b). Středně devonská vápencová sedimentace (eifel-givet) je ve studované oblasti reprezentována hlavně mikritickými a biomikritickými vápenci. Laterálně se zastupují s břidlicemi stínavsko-chabičovského souvrství (Bábek et al. 1994). Fosfority se vyskytují hlavně v biomikritických a biodetritických jeseneckých vápencích, které jsou patrně frasnského stáří (Bábek et al. 1994). Vápence tournaiského stáří jsou faunisticky chudší a vyznačují se vysokou mírou fragmentace jednotlivých elementů konodontů a hojným výskytem redeponované starší fauny (Bábek 2001a) prř́padně i fosforitů.

Tab. 1: Lokalizace (SJTSK) míst odběrů studovaných fosforitů použitých v této studii. Tab. 1: Locations (SJTSK) of studied phosphorite samples used in this study.

\begin{tabular}{|c|c|c|c|c|c|c|}
\hline dok. b. & mapa & výchoz & obec & šířka & délka & hornina \\
\hline R012 & 24214 & lom & Jesenec & $49^{\circ} 36^{\circ} 43.3443^{\prime \prime} \mathrm{N}$ & $16^{\circ} 51^{\prime} 45.4821^{\prime \prime} \mathrm{E}$ & biomikritický vápenec \\
\hline DK003 & 24214 & lom & Jesenec & $49^{\circ} 36^{\prime} 55.5496^{\prime \prime} \mathrm{N}$ & $16^{\circ} 51^{\prime} 42.6136^{\prime \prime} \mathrm{E}$ & biomikritický vápenec \\
\hline $17 \mathrm{~K} 11$ & 24214 & lom & Dzbel & $49^{\circ} 36^{\circ} 47.2611^{\prime \prime} \mathrm{N}$ & $16^{\circ} 51^{\prime} 37.0369^{\prime \prime} \mathrm{E}$ & biomikritický vápenec \\
\hline
\end{tabular}

\section{Výsledky \\ Charakteristika vápenců}

Mezi makroskopicky pozorovatelnými fosilními organickými zbytky se nejčastěji vyskytují články krinoidů a jejich úlomky. Lokálně vápence obsahují písčitou nebo jílovitou příměs (místy se vyskytují málo mocné vrstvy vápnitých břidlic). V některých polohách vápenců o mocnosti až $1,5 \mathrm{~m}$ jsou př́tomné až $30 \mathrm{~mm}$ dlouhé úlomky pyroklastického materiálu. Jedná se o drobné vulkanické lapilly, jejichž základní hmota (původně vulkanické sklo) je změněna na směs chloritu, albitu, jílových minerálů a kalcitu (určeno pomocí optického mikroskopu). Místy jsou patrné drobné oválné nebo ostrohranné úlomky fosforitů (obr. 1). Jesenecké vápence jsou postižené slabou regionální metamorfózou a deformací. Kvůli rekrystalizaci byla v mnoha případech modifikována struktura vápenců (vznik středně zrnitého sparitického kalcitu v důsledku rekrystalizace podél nově vzniklých ploch metamorfní foliace) a poškození fosilních zbytků (částečně rekrystalované články krinoidů).

\section{Texturní charakteristika fosforitů}

Vápence obsahují několik mm až $25 \mathrm{~mm}$ velké ostrohranné nebo oválné úlomky černých fosforitů. Fosfority jsou nepravidelně rozptýlené ve vápencích s různým stupněm deformace (obr. 1). Většinou jsou obklopeny poměrně čistým biomikritickým vápencem. Lokálně jsou asociovány s vápenci, které obsahují příměs klastického nebo vulkanoklastického materiálu. Dominují ostrohranné klasty fosforitu (obr. 2a) méně časté jsou klasty které nesou známky opracovánív důsledku transportu. 

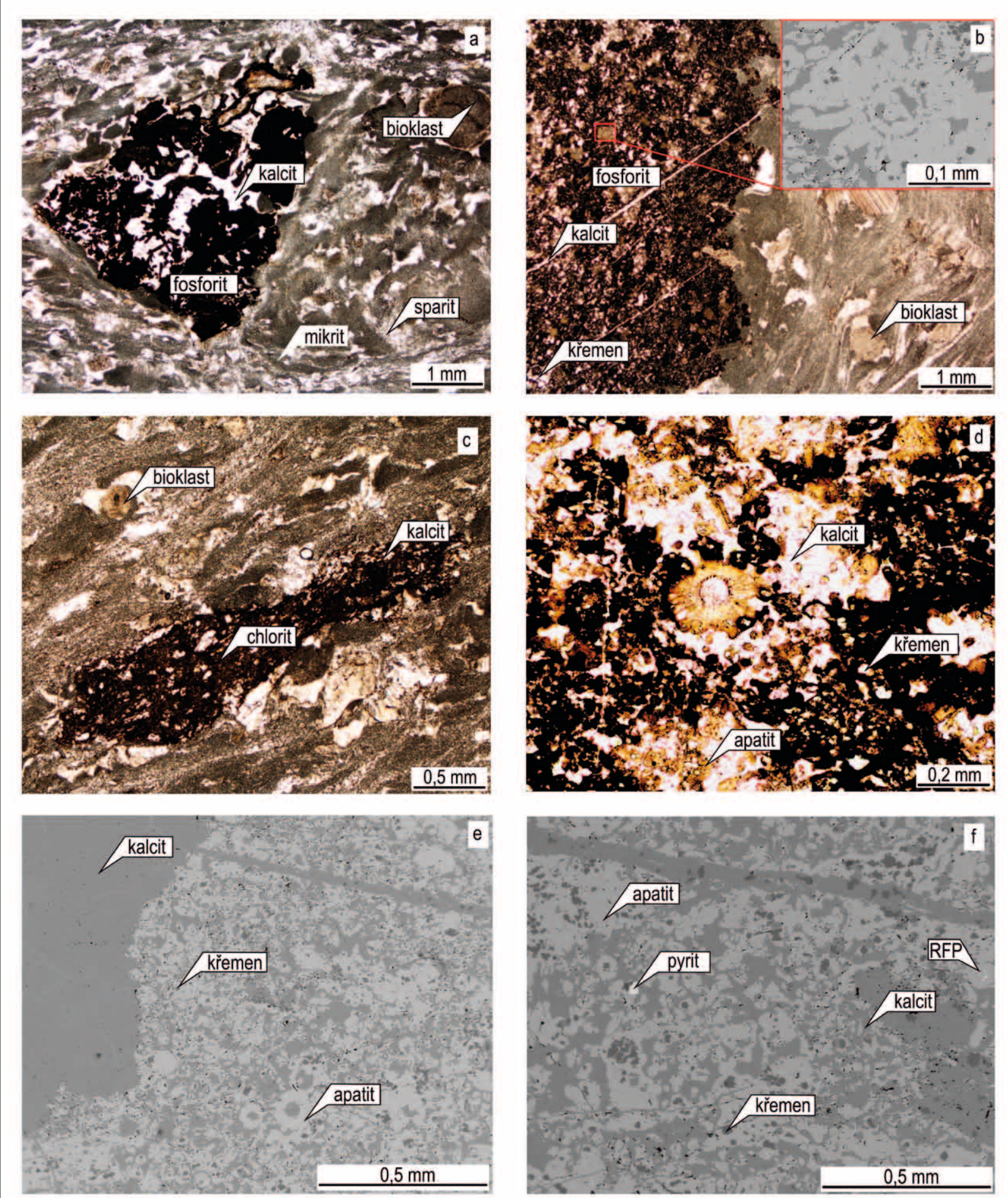

Obr. 2: Mikrofotografie vápenců s fosfority: a - ostrohranný úlomek fosforitu pronikaný žilkami kalcitu (dokumentační bod DK003D); b - oválná konkrece fosforitu (dokumentační bod R012), PPL s detailem radiálně paprsčitého agregátu apatitu (BSE); c - deformovaná vulkanická lapilla ve vápenci z lomu severně od obce Dzbel (dokumentační bod 17K11), XPL; d - sféroidické agregáty apatitu v konkreci fosfátu (dokumentační bod R012), PPL; e - okraj oválné konkrece fosforitu (dokumentační bod R012), BSE; f - struktura konkrece fosforitu (dokumentační bod R012), RFP = patrně relikt framboidálního pyritu, BSE.

Fig. 2: Microphotographs of limestones with phosphorites: a - angular fragment of phosphorite penetrated by calcite veins (documentation point DK003D); b - oval phosphorite concretion (documentation point R012, PPL) with detail of the apatite forming a radial aggregate (BSE); $\mathrm{c}$ - deformed volcanic lapilli within limestone from a quarry north of village Dzbel (documentation point 17K11), XPL; $d$ - spheroidal aggregates of apatite in phosphatic concretion (documentation point R012), PPL; e - edge oval phosphorite concretion (documentation point R012), BSE; $\mathrm{f}$ - structure of phosphorite concretion (documentation point R012), $\mathrm{RFP}=$ possible relic of framboidal pyrite, BSE. 
Tab. 2: Reprezentativní složení apatitu ze vzorku R012 Tab. 2: Representative compositions of apatite from sample R012

\begin{tabular}{|l|r|r|r|r|}
\hline \multicolumn{1}{|c|}{ č. analýzy } & \multicolumn{1}{c|}{$\mathbf{1}$} & \multicolumn{1}{c|}{$\mathbf{2}$} & \multicolumn{1}{c|}{$\mathbf{3}$} & \multicolumn{1}{c|}{} \\
\hline $\mathrm{P}_{2} \mathrm{O}_{5}$ & 40,79 & 40,99 & 40,42 & 40,59 \\
\hline $\mathrm{SiO}_{2}$ & 0,08 & 0,04 & 0,05 & 0,09 \\
\hline $\mathrm{CaO}$ & 54,87 & 55,81 & 55,04 & 55,53 \\
\hline $\mathrm{La}_{2} \mathrm{O}_{3}$ & 0,01 & 0,00 & 0,00 & 0,05 \\
\hline $\mathrm{Pr}_{2} \mathrm{O}_{3}$ & 0,00 & 0,08 & 0,00 & 0,06 \\
\hline $\mathrm{Nd}_{2} \mathrm{O}_{3}$ & 0,00 & 0,00 & 0,04 & 0,14 \\
\hline $\mathrm{Y}_{2} \mathrm{O}_{3}$ & 0,03 & 0,00 & 0,00 & 0,00 \\
\hline $\mathrm{ThO}_{2}$ & 0,00 & 0,00 & 0,08 & 0,00 \\
\hline $\mathrm{UO}_{2}$ & 0,08 & 0,00 & 0,03 & 0,09 \\
\hline $\mathrm{FeO}$ & 0,10 & 0,07 & 0,14 & 0,13 \\
\hline $\mathrm{MnO}$ & 0,04 & 0,00 & 0,03 & 0,00 \\
\hline $\mathrm{F}$ & 4,47 & 4,60 & 4,56 & 4,42 \\
\hline $\mathrm{Cl}$ & 0,00 & 0,00 & 0,02 & 0,02 \\
\hline $\mathrm{OH}$ & $-0,32$ & $-0,36$ & $-0,36$ & $-0,29$ \\
\hline $\mathrm{Celkem}$ & 100,16 & 101,24 & 100,04 & 100,81 \\
\hline $\mathrm{O}=\mathrm{F}, \mathrm{Cl}$ & 1,88 & 1,93 & 1,93 & 1,86 \\
\hline $\mathrm{P}$ & 2,940 & 2,929 & 2,916 & 2,913 \\
\hline $\mathrm{Si}$ & 0,007 & 0,003 & 0,004 & 0,007 \\
\hline $\mathrm{Ca}$ & 5,006 & 5,047 & 5,025 & 5,042 \\
\hline $\mathrm{La}$ & 0,000 & 0,000 & 0,000 & 0,002 \\
\hline $\mathrm{Pr}$ & 0,000 & 0,002 & 0,000 & 0,002 \\
\hline $\mathrm{Nd}$ & 0,000 & 0,000 & 0,001 & 0,004 \\
\hline $\mathrm{Y}$ & 0,002 & 0,000 & 0,000 & 0,000 \\
\hline $\mathrm{Th}$ & 0,000 & 0,000 & 0,002 & 0,000 \\
\hline $\mathrm{U}$ & 0,001 & 0,000 & 0,001 & 0,002 \\
\hline $\mathrm{Fe}$ & 0,007 & 0,005 & 0,010 & 0,009 \\
\hline $\mathrm{Mn}$ & 0,003 & 0,000 & 0,002 & 0,000 \\
\hline $\mathrm{Celkem}$ & 7,966 & 7,988 & 7,961 & 7,980 \\
\hline $\mathrm{Fluorapatit}$ & 1,0 & 1,0 & 1,0 & 1,0 \\
\hline $\mathrm{Chlorapatit}$ & 0,0 & 0,0 & 0,0 & 0,0 \\
\hline $\mathrm{Hydroxylapatit}$ & 0,0 & 0,0 & 0,0 & 0,0 \\
\hline & & & & \\
\hline & & & \\
\hline & & & & \\
\hline
\end{tabular}

Koncentrická stavba některých fosforitů indikuje, že jsou to konkrece (obr. 2b). V př́padě studovaného vzorku R012 byl fosforit interpretován jako konkrece až na základě charakteru kontaktu fosforitu s okolím. Pro detailnější studium byly zvoleny tři vzorky vápenců, které obsahují fosfority (tab. 1).

Ostrohranné fosfority se vyskytují společně s vulkanickou příměsí a krinoidových článků (vzorky DK003 a 17K11). Drobné vulkanické lapilly světle zelené barvy, jsou na rozdíl od fosforitu výrazně postiženy deformací (obr. 2c). Ostrohranné klasty fosforitu mají v mikroskopu brekciovitou stavbu (obr. 2a). Tato brekcie se skládá z masivních jemně zrnitých tmavých úlomků tmelených kalcitem. Tmavý jemnozrnný materiál byl na základě optických vlastností určen jako apatit s příměsí organické hmoty (hmota nemá amorfní charakter).

Vzorek R012 je klasifikován jako silně rekrystalovaný biomikritický vápenec s malou příměsí vulkanického materiálu (ostrohranný úlomek slabě metamorfovaného bazaltoidu; obr. 2c). Konkrece fosforitu (obr. 1) má eliptický tvar o rozměrech $10 \times 21 \mathrm{~mm}$ a poměrně komplikovanou vnitřní stavbu (obr. 2b). Základní hmota je tvořená xenomorfním až hypautomorfním apatitem, kalcitem a křemenem. Apatit je v optickém mikroskopu tmavý, a to v důsledku příměsi organické hmoty (obr. 2d). Místy jsou patrné radiálně paprsčité agregáty jemně sloupcovitého apatitu (obr. 2b), jejichž průměr může dosáhnout až $0,2 \mathrm{~mm}$ (obr. 2d). Radiálně paprsčité agregáty sloupcovitých a jehličkovitých krystalů apatitu jsou obklopeny kalcitem (obr. 2b, e). V centrální části těchto agregátů může být apatit, kalcit nebo xenomorfní křemen (obr. 2f). Apatit v okolí sférulitů bývá většinou xenomorfní a je zatlačován kalcitem (obr. 2e, f). Vzácně se v konkreci vyskytují xenomorfní zrna pyritu obklopená křemenem nebo apatitem. $\mathrm{V}$ jednom př́padě je patrná eliptická struktura, typická pro relikt framboidálního pyritu (obr. 2f; srovnej např́iklad Ding et al. 2014). Vzácně se zrna křemene shlukují do větších agregátů (obr. 2f). Kontakt konkrece s okolním vápencem je nerovný (zdá se, že jsou karbonáty apatitem zatlačovány, obr. 2b, e). Konkrece je prorážena mladšími kalcitovými žilami (obr. 2e).

\section{Mineralogie fosforitů}

Fluorapatity z fosfátové konkrece ze vzorku R012 obsahují podle výsledků elektronové mikroanalýzy 0,07 až 0,14 hm. \% FeO, a 0,00 až 0,04 hm. \% MnO (tab. 2). Obsahy REE (až $0,24 \mathrm{hm}$. \% oxidů LREE), Th (až 0,08 hm. \% ThO ${ }_{2}$ ) a U (až 0,09 hm. \% UO $\mathrm{UO}_{2}$ ) jsou nízké. Karbonáty v mezerní hmotě mezi fluorapatity a v okolním vápenci mají podobné chemické složení. Jedná se o kalcit s nízkým obsahem $\mathrm{Mg}$ (až 0,43 hm. \% MgO) a Fe (0,06 až $0,14 \mathrm{hm}$. \% FeO).

\section{Diskuze}

Dva ostrohranné úlomky fosfátů (DK003 a 17K11) můžeme podle klasifikace Trappeho (2001) označit jako litoklasty („phoslithoclasts“). Tento typ fosforitů obvykle vzniká v mělkovodním prostředí karbonátových platforem $\mathrm{v}$ důsledku prrínosu fosforu hlubokomořskými vzestupnými proudy (např. Paytan a McLaughlin 2007; Bolourchifard et al. 2019). Jedná se o tenké vrstvičky fosfátu na povrchu sedimentu („hardground“), kde dochází $\mathrm{k}$ fosfatizaci mikritu a vysrážení fosfátů v důsledku činnosti řas nebo bakterií (Trappe 2001; Guilbert a Park 2007). Takto vzniklé fosfátové krusty pak byly destruovány v důsledku vlnění souvisejícího s bouřkovou činností nebo erupcí sopky (Trappe 2001; Bolourchifard et al. 2019; Gál et al. 2020)

Radiálně paprsčité struktury o velikosti od 0,002 mm do $0,2 \mathrm{~mm}$ (obr. $2 \mathrm{~d}$, e) zjištěné ve fosforitové konkreci z lomu s. od obce Jesenec (R012) naznačují specifický způsob jejího vzniku. Podobné struktury byly popsány z devonských břidlic (Chattanooga) z Tennessee ve Spojených Státech Amerických, kde jsou ale jejich rozměry úzce ohraničeny na 0,001 až $0,003 \mathrm{~mm}$ (Li a Schieber 2015). Ve zmíněném případě je vznik těchto struktur spojován s mikroorganismy. Zejména bakterie oxidující síru mohou hrát jak pasivní role, tak i aktivní role při srážení fosfátů. Buňky bakterií mohou např́klad sloužit jako šablony pro nukleace a růst apatitu ve fosfátem přesycených roztocích (Sigel et al. 2008). Podobné fosfatické bakterie o velikosti několika setin mm se již podařilo ve fosilním záznamu nalézt (Cosmidis et al. 2013). Vznik těchto fosfátových 
konkrecí však také může souviset s činností sirných bakterií, které aktivně uvolňují fosfáty během degradace organických sloučenin (např. Hirschler et al. 1990).

Variabilita velikosti námi pozorovaných radiálně paprsčitých struktur je mnohem větší, což nelze vysvětlit ani metamorfní rekrystalizací (obr. 2d-f). Navíc námi studované agregáty apatitu nemají vícevrstvou soustřednou stavbu typickou pro struktury spojované s činností mikroorganismů (Cosmidis et al. 2013; Li a Schieber 2015). Relikty krystalů pyritu (obr. 2f) uzavřené v apatitu svědčí o redukčních podmínkách $\mathrm{v}$ počátečních fázích vývoje konkrece. K vzniku pyritu mohlo docházet i při poměrně malé hloubce pohřbení pod mořským dnem, kdy ve vrstvě nezpevněného vápence mohly panovat redukční podmínky (např. Li a Schieber 2015). Př́tomnost křemene, který uzavírá úlomky pyritu, je pak důkazem, že v další fázi docházelo k silicifikaci (obr. 2e, f), která mohla souviset s oxidací pyritu. K rozpadu pyritu obvykle dochází $\mathrm{v}$ důsledku kolísání oxidačně-redukčních podmínek a hodnot $\mathrm{pH} \mathrm{v}$ sedimentu během jeho odkrytí v důsledku erozní činnosti v mělkovodním prostředí (např. Li a Schieber 2015) nebo v důsledku perkolace oxidačními diagenetickými roztoky. Tyto procesy způsobily oxidaci dříve vytvořeného pyritu, což vedlo ke snížení $\mathrm{pH}$ vody $\mathrm{v}$ pórech a nucenému rozpouštění biogenního fosfátu a jeho následné precipitaci (např. Schieber 2007). Takto vzniklé fosfátové roztoky pak mohly nahradit produkty oxidace pyritu a vznikl tak agregát tvořený podlouhlými krystaly apatitu. Tuto teorii potvrzují také pozorování na okrajích konkrece, kde je patrné epigenetické nahrazování uhličitanových zrn apatitem (obr. 2e)

\section{Závěry}

Severně od obcí Dzbel a Jesenec byly v jeseneckých vápencích devonského až karbonského stáří nalezeny několik mm až $25 \mathrm{~mm}$ velké ostrohranné a oválné úlomky černých fosforitů. Na základě tvaru byly fosfority rozděleny do dvou skupin: ostrohranné intraklasty a oválné konkrece. Pro detailní mikroskopické studium byly zvoleny dva intraklasty a jedna konkrece.

Intraklasty jsou úlomky vrstev fosforitů vzniklých $\mathrm{v}$ důsledku činnosti řas nebo bakterií v mělkovodním prostředí na karbonátovém podkladu poblíž vulkanických center. K destrukci těchto fosfátových krust mohlo dojít v důsledku vlnění souvisejícího s bouřkovou činností nebo erupcí sopky. Souvislost vzniku intraklastů s vulkanickou aktivitou naznačuje přítomnost vulkanického materiálu $\mathrm{v}$ asociaci s těmito fosfority.

Texturní vztahy mezi apatitem, pyritem a kalcitem zjištěné ve studované konkreci indikují její polyfázový vznik. V první fázi předpokládáme krystalizaci pyritu $\mathrm{v}$ anoxickém prostředí $\mathrm{v}$ počátečních fázích diageneze biomikritického vápence. Snížení $\mathrm{pH}$ vody v pórech $\mathrm{v}$ důsledku následné oxidace pyritu vedlo k rozpouštění biogenního fosfátu a jeho následné precipitaci v konkrecích. Kolísání oxidačně-redukčních podmínek a hodnot pH v sedimentu během diagenetických pochodů vedlo k silicifikaci a následné fosfatizaci pyritových konkrecí.

\section{Poděkování}

Tento prríspěvek byl vytvořen v rámci řešení DKRVO/ČGS (2018-2022), za finanční podpory projektů České geologické služby číslo 321180 („Základní geologické mapováni“). Autoři děkují Tomášovi Kumpanovi a Daliborovi Matýskovi za cenné připomínky $k$ manuskriptu.

\section{Literatura}

Bábek, O. (1996). Tafonomie a biofacie konodontových společenstev jeseneckých vápenců na Drahanské vrchovině a jejich význam pro faciální analýzu. - Geologické výzkumy na Moravě a ve Slezku v r. 1995, 3, 76-78. Brno.

Bábek, O. (1997). Microfacies analysis of Dcvonian to Lower Carboniferous carbonates and its impact on the interpretation of internal architecture of the Konice-Mladeč Belt, Moravia, Czech Republic. - Journal of the Czech Geological Society, $42,59-73$.

Bábek, O. (2001a). Konodontová biostratigrafie jeseneckých vápenců na území konicko - mladečského pruhu na Moravě, Český masív. - Acta Musei Moraviae, Scientiae Geologicae, 86, 1-2, 161-173. Brno.

Bábek, O. (2001b). Konodontová biostratigrafie vápenců přechodního (ludmírovského) vývoje na území konicko-mladečského pruhu, Drahanská vrchovina, Český masív. - Př́rodovědné studie Muzea Prostějovska, 4, 17-29. Prostějov.

Bábek, O., Kalvoda, J., Krejčí, Z. (1994). New stratigraphical results in the Paleozoic of the Drahanská vrchovina Upland (Moravia, Czech Republic). - Journal of the Czech Geological Society, 39, 2-3, 197-204. 
Bábek, O., Janoška, M. (1997). Tectonic evolution of the Konice-Mladeč Belt: Structural analysis and a facies disjunction. - Acta Universitatis Palackianae Olomucensis, Facultas Rerum Naturalium, Geologica, 35, 31-35.

Bábek, O., Tomek, Č., Melichar, R., Kalvoda, J., Otava, J. (2006). Structure of unmetamorphosed Variscan tectonic units of the southern Moravio-Silesian zone, Bohemian Massif, (a review). - Neues Jahrbuch für Geologie und Paläontologie Abhandlungen, 239 (1), 37-75. Stuttgart. https://doi.org/ 10.1127/njgpa/239/2006/37

Barth, V. (1960). Devonský vulkanismus Šternbersko-hornobenešovského pásma v Nízkém Jeseníku. - Acta Universitatis Palackianae Olomucensis, Facultas Rerum Scientiarum 1: Geographica-geologica, 1, 5-131.

Barth, V. (1964). Faciální vývoj vulkanického komplexu v jižní části konicko-mladečského devonu na Drahanské vrchovině. Acta Universitatis Palackianae Olomoucensis, Geographica-geologica Olomouc, Universita Palackého, 6, $13-64$.

Bolourchifard, F., Fayazi, F., Mehrabi, B., Memarkouchehbagh, A. (2019). Evidence of high-energy storm and shallow water facies in Pabdeh sedimentary phosphate deposit, Kuhe-Lar-anticline, SW Iran. - Carbonates and Evaporites, 34(4), $1703-1721$. https://doi:10.1007/s13146-019-00520-4

Cosmidis, J., Benzerara, K., Gheerbrant, E., Estève, I., Bouya, B., Amaghzaz, M. (2013). Nanometer-scale characterization of exceptionally preserved bacterial fossils in Paleocene phosphorites from Ouled Abdoun (Morocco). - Geobiology, 11 (2), 139-153.

Ding, H., Yao, S., Chen, J. (2014). Authigenic pyrite formation and re-oxidation as an indicator of an unsteady-state redox sedimentary environment: Evidence from the intertidal mangrove sediments of Hainan Island, China. - Continental Shelf Research, 78, 85-99. doi:https://doi.org/10.1016/j.csr.2014.02.011

Dvořák, J. (1994). Variský flyšový vývoj v Nízkém Jeseníku na Moravě a ve Slezsku. - Special Papers No. 3. Czech Geological Survey. Praha.

Dvořák, J. (1996). Ukončení komplexního výzkumu vrtů v konickém paleozoiku (sz. část Drahanské vrchoviny). - Zprávy o geologických výzkumech v roce 1995. ČGU, Brno, 29, 54-55.

Engel, W., Franke, W. (1983). Flysch sedimentation: its relations to tectonism in the European Variscides. - In: Martin, H., Eder, F. W. (eds). - Intracontinental Fold Belts. Springer, Berlin, 289-322.

Finger, F., Steyrer, H. P. (1995). A tectonic model for the eastern Variscides: Indication from a chemical study of amphiboles in the south-eastern Bohemian Massif. - Geologica Carpathica, 46, 137-151.

Gál, P., Polgári, M., Józsa, S., Gyollai, I., Kovács, I., Szabó, M., Fintor, K. (2020). Contribution to the origin of Mn-U-Be-HREE-enrichment in phosphorite, near Bükkszentkereszt, NE Hungary. - Ore Geology Reviews, 125, 103-665. https://doi. org/10.1016/j.oregeorev.2020.103665

Guilbert, J. M., Park, C. F. (2007). The geology of ore deposits. - Waveland Press. Long Grove. 985 s.

Hirschler, A., Lucas, J., Hubert, J. C. (1990). Apatite genesis: a biologically induced or biologically controlled mineral formation process?. - Geomicrobiology Journal, 8 (1), 47-56.

Hladil, J. (1994). Moravian Middle and Late Devonian Buildups: evolution in time and space with respect to the Laurussian shelf. - Courier Forschungsinstitut Senckenberg, 172, 111-125.

Chlupáč, I. (1959). K stratigrafii drahanského vývoje moravského devonu. - Věstník Ústředního ústavu geologického, 35, 329-332, Academia, Praha.

Chlupáč, I., Svoboda, J. (1963). Geologické poměry konicko-mladečského devonu na Drahanské vrchovině. - Sborník Ústř̌edního ústavu geologického, 28, 347-386. Praha.

Chlupáč, I. (1964). K stratigrafickému delení moravského devonu. - Časopis pro mineralogii a geologii, 9, 3, 309-316, Praha.

Chlupáč, I., Brzobohatý, R., Kovanda, J., Stráník, Z. (2002). Geologická minulost České republiky. Academia, Praha.

Kalvoda, J., Bábek, O., Fatka, O., Leichmann, J., Melichar, R., Nehyba, S., Špaček, P. (2008). Brunovistulian terrane (Bohemian Massif, Central Europe) from late Proterozoic to late Paleozoic: a review. - International Journal of Earth Science, 97, 497-518.

Kalvoda J., Bábek O. (2010). The Margins of Laurussia in Central and Southeast Europe and Southwest Asia. - Gondwana Research, 17, 2-3, 526-545.

Kettner, R. (1965). Tektonika konicko - mladečského devonu na drahanské vrchovině. - Věstník Ústředního ústavu geologického, 40, 6, 461-466. Praha.

Kumpera, O. (1983). Geologie spodního karbonu jesenického bloku. - Knihovna Ústředního Ústavu geologického, 59, $172 \mathrm{s.}$

Li, Y., Schieber, J. (2015). On the origin of a phosphate enriched interval in the Chattanooga Shale (Upper Devonian) of Tennessee - A combined sedimentologic, petrographic, and geochemical study. - Sedimentary Geology, 329, 40-61. https:// doi.org/10.1016/j.sedgeo.2015.09.005

Paytan, A., McLaughlin, K. (2007). The Oceanic Phosphorus Cycle. - Chemical Reviews, 107(2), 563-576. https://doi:10.1021/ cr0503613

Schieber, J. (2007). Oxidation of detrital pyrite as a cause for Marcasite Formation in marine lag deposits from the Devonian of the eastern US. - Deep Sea Research Part II: Topical Studies in Oceanography 54 (11-13), 1312-1326.

Sigel, A., Sigel, H., Sigel, R. K. (2008). Biomineralization: From Nature to Application 4. - John Wiley \& Sons. Chichester. $671 \mathrm{~s}$.

Streit, R. (2019). Vulkanologická a petrografická charakteristika podmořských vulkanických hornin z jižní části konicko-mladečského pruhu. - MS, bakalářská práce. Př́rodovědecká fakulta Masarykovy univerzity. Brno.

Svoboda, J., Prantl, F. (1951). Příspěvek ke stratigrafii devonských bradel na Drahanské vysočině. - Věstník Ústředního ústavu geologického, 26, 5, 263-273, Praha.

Svoboda, J., Prantl, F. (1954). Stratigraficko-tektonický výzkum devonských bradel na Drahanské vysočině. - Zprávy o geologických výzkumech v r. 1953, 194-198, Praha.

Trappe, J. (2001). A nomenclature system for granular phosphate rocks according to depositional texture. - Sedimentary Geology, 145(1), 135-150. https://doi.org/10.1016/S0037-0738(01)00103-8

Zukalová, V., Chlupáč, I. (1982). Stratigrafická klasifikace nemetamorfovaného devonu moravskoslezské oblasti. - Časopis pro mineralogii a geologii, 7, 3, 225-241, Praha. 